J. Clin. Chem. Clin. Biochem.

Vol. 27, 1989. pp. 185-189

(C) 1989 Walter de Gruyter \& Co.

Berlin - New York

\title{
The Determination of Haemoglobin as Cyanhaemiglobin or as Alkaline Haematin D-575 Comparison of Method-Related Errors
}

By $R$. Zander, W. Lang

Physiologisches Institut der Universität Mainz, Mainz, FRG and

H. U. Wolf

Abteilung Pharmakologie und Toxikologie der Universität Ulm, Ulm, FRG

(Received March 20/September 6, 1985)

Summary: In order to compare the accuracy of haemoglobin $(\mathrm{Hb})$ determination methods, the commonly used cyanhaemiglobin (HiCN) method and the recently developed alkaline haematin D-575 (AHD) method (R. Zander, W. Lang \& H. U. Wolf (1984) Clin. Chim. Acta 136, 83-93; H. U. Wolf, W. Lang \& R. Zander (1984) Clin. Chim. Acta 136, 95-104) were tested with respect to method-related errors such as plasma, cell, and $\mathrm{Hb}$ errors.

Both methods yield a series of more or less significant errors which generally lead to an overestimation of the $\mathrm{Hb}$ concentration in the order of $1 \%$. However, in all three cases of plasma errors, i. e. normal plasma error, plasma error in lipaemic blood, and plasma error in bilirubinaemic blood, the AHD method shows significantly lower values of errors than the $\mathrm{HiCN}$ method.

In the case of cell errors such as ghost and leukocyte errors, the overestimation of the Hb concentration by the $\mathrm{HiCN}$ method is $60 \%$ higher than that by the AHD method. In the case of $\mathrm{Hb}$ errors such as fetal $\mathrm{Hb}$ and carboxy $\mathrm{Hb}$ errors, there is a significant overestimation of the $\mathrm{Hb}$ concentration by the $\mathrm{HiCN}$ method, which amounts $3 \mathrm{~min}$ after mixing of blood and $\mathrm{HiCN}$ solution to $0.7 \%$ in the case of fetal $\mathrm{Hb}$ and to $13.2 \%$ in the case of carboxy $\mathrm{Hb}$. The latter value yields an overestimation of $1.3 \%$, when $10 \%$ carboxy $\mathrm{Hb}$ in a blood sample is present. In contrast, there is no detectable overestimation after $3 \mathrm{~min}$ in the case of the AHD method.

Thus, the AHD method provides a higher accuracy in $\mathrm{Hb}$ determination than the commonly used HiCN method.

\section{Introduction}

A new method for the rapid and accurate measurement of haemoglobin has been developed as an alternative to the conventional HiCN method (1). This method is based on the conversion of all haem, haemoglobin, and haemiglobin species into a stable end product by an alkaline solution of a non-ionic detergent (e.g. Triton X-100). The reaction product, designated as alkaline haematin D-575 (AHD), is very stable and shows a characteristic absorption peak at
$575 \mathrm{~nm}$. As compared to the $\mathrm{HiCN}$ method, the determination of haemoglobin by the AHD method offers several advantages such as

(a) high stability of the AHD reagent and of the conversion product,

(b) decreased conversion time of all haemoglobin species into the end product, and

(c) the possibility of standardization with a primary standard, i. e. purified crystalline chlorohaemin (2). 
As demonstrated by several authors ( $3-9)$, the $\mathrm{HiCN}$ method shows a series of different errors which can lead to an overestimation of the $\mathrm{Hb}$ concentration. Therefore, the two methods are compared with respect to plasma and cell errors, and errors caused by delayed conversion of carboxy and fetal $\mathrm{Hb}$ in the present paper.

\section{Materials and Methods}

Chemicals: Triton $\mathrm{X}-100$, virtually peroxide-free, and $\mathrm{NaOH}$ were obtained from Merck, Darmstadt. Bilirubin was used as Dade ${ }^{\circledast}$ Bilirubin Control (containing albumin), from Dade Division, American Hospital Supply Corporation, Miami, USA.

Chlorohaemin was an own preparation according to a method described in detail in a special paper ${ }^{1}$ ).

Blood was heparinized human blood. The blood was treated with pure CO (Linde AG, Mainz-Kastel, FRG) to form carboxyhaemoglobin.

The HiCN standard reagent solution according to Van Kampen \& Zijlstra was obtained from Merck, Darmstadt, and from Boehringer, Mannheim.

The AHD reaction solution consisted of $2.5 \%$ Triton $\mathrm{X}-100$ and $0.1 \mathrm{~mol} / 1 \mathrm{NaOH}(\mathrm{pH}=13)$.

The two methods were tested using $20 \mu \mathrm{l}$ of blood or plasma $+5 \mathrm{ml} \mathrm{HiCN}$ reagent in the case of the $\mathrm{HiCN}$ method, and 20 $\mu l$ of blood or plasma $+3 \mathrm{ml} \mathrm{AHD}$ reagent in the case of the AHD method, the absorbance being measured against the corresponding reagent solutions as blanks.

All photometer readings were run in the visible range at 575 and $540 \mathrm{~nm}$, respectively, on a Zeiss precision photometer PM 6 (band width $2 \mathrm{~nm}$, wavelength accuracy $\pm 0.5 \mathrm{~nm}$ ).

The results for both methods listed in the tables are expressed as absorbance values (A) and haemoglobin concentration in $\mathrm{g} / \mathrm{dl}$. The latter values were obtained using equation (1)

$$
[\mathrm{Hb}](\mathrm{g} / \mathrm{dl})=36.77 \cdot \mathrm{A}_{540 \mathrm{~nm}}
$$

in the case of the $\mathrm{HiCN}$ method, and using equation (2)

$$
[\mathrm{Hb}](\mathrm{g} / \mathrm{dl})=34.96 \cdot \mathrm{A}_{575 \mathrm{~nm}}
$$

in the case of the AHD method.

1) Chlorohaemin with a purity of $>99 \%$ can be obtained from Serva, Heidelberg FRG.
The numerical factor in eq. (1) and eq. (2) is a conversion factor to obtain the $\mathrm{Hb}$ concentration in $\mathrm{g} / \mathrm{dl}$ from absorbance values including the molecular weight of haemoglobin, the millimolar absorption coefficient and the dilution ratio of blood with respect to $\mathrm{HiCN}$ (14) and to chlorohaemin (2).

\section{Results}

\section{Plasma errors}

\section{Normal plasma errors and its dependence on haema-} tocrit value

The normal plasma error was measured using 14 samples of plasma from 8 persons. Each sample was determined 5 times $(n=70)$. The measured absorbance amounts to $0.0053 \pm 0.0017$ in the $\mathrm{HiCN}$ method and to $0.0027 \pm 0.0011$ in the AHD method. This normal plasma error obviously results in an overestimation of the $\mathrm{Hb}$ concentration, whereby both the absolute and relative degree of this overestimation depends on the haematocrit value. These calculated results are listed in table 1 . At all $\mathrm{Hb}$ concentrations considered, the AHD procedure shows markedly lower positive errors than the reference $\mathrm{HiCN}$ method.

\section{Plasma error in lipaemic blood}

The plasma error in lipaemic blood was measured using $20 \mu \mathrm{l}$ of lipaemic plasma from 2 test persons in 15 determinations. The absorbance value for the $\mathrm{HiCN}$ method was $0.0103 \pm 0.0029$, and for the AHD method $0.0074 \pm 0.0043$, and these are expressed in table 1 as $\mathrm{Hb}$ in $\mathrm{g} / \mathrm{dl}$. In addition, this table contains the positive relative errors calculated for lipaemic blood containing $15 \mathrm{~g} / \mathrm{dl}$ (haematocrit $\equiv 0.45$, plasma volume $=0.55$ of the blood volume). Again the overestimation of $\mathrm{Hb}$ is lower in the case of the AHD method than with the reference method.

\begin{tabular}{|c|c|c|c|c|c|c|c|}
\hline \multirow[t]{3}{*}{ Kind of plasma } & \multirow{3}{*}{$\begin{array}{l}\text { Haemato- } \\
\text { crit }\end{array}$} & \multirow{3}{*}{$\begin{array}{l}\text { Hb concen- } \\
\text { tration } \\
\text { [g/dl] }\end{array}$} & \multirow{3}{*}{$\begin{array}{l}\text { Residual } \\
\text { plasma } \\
\text { volume } \\
{[\mu l]}\end{array}$} & \multicolumn{4}{|c|}{ Error in the $\mathrm{Hb}$ determination } \\
\hline & & & & \multicolumn{2}{|c|}{ HiCN method } & \multicolumn{2}{|c|}{ AHD method } \\
\hline & & & & {$[\mathrm{g} / \mathrm{dl}]$} & {$[\%]$} & [g/di] & {$[\%]$} \\
\hline $\begin{array}{l}\text { Normal } \\
\text { calculated } \\
\text { influence of } \\
\text { haematocrit }\end{array}$ & $\begin{array}{l}- \\
0.45 \\
0.30 \\
0.15\end{array}$ & $\begin{array}{r}- \\
15 \\
10 \\
5\end{array}$ & $\begin{array}{l}20 \\
11 \\
14 \\
17\end{array}$ & $\begin{array}{l}+0.195 \\
+0.11 \\
+0.14 \\
+0.17\end{array}$ & $\begin{array}{l}- \\
+0.77 \\
+1.47 \\
+3.57\end{array}$ & $\begin{array}{l}+0.094 \\
+0.052 \\
+0.066 \\
+0.080\end{array}$ & $\begin{array}{l}- \\
+0.35 \\
+0.45 \\
+0.54\end{array}$ \\
\hline Lipaemic & 0.45 & 15 & 11 & +0.209 & +1.4 & +0.143 & +0.95 \\
\hline Bilirubinaemic & 0.45 & 15 & 11 & +0.071 & +0.47 & +0.029 & +0.19 \\
\hline
\end{tabular}

Tab. 1. Error of $\mathrm{Hb}$ determination caused by normal and pathological plasma 


\section{Plasma error in bilirubinaemic blood}

For the determination of this error, $20 \mu \mathrm{l}$ of a freshly prepared bilirubin solution of $200 \mathrm{mg} / 1(\mathrm{n}=10)$ were used. The results, shown in table 1 , are expressed as $\mathrm{Hb}$ in $\mathrm{g} / \mathrm{dl}$ and as the relative $\mathrm{Hb}$ overestimation at $15 \mathrm{~g} / \mathrm{dl}$ (haematocrit $=0.45$, i.e. 0.55 of the whole blood volume is assumed to be plasma). In analogy to the plasma errors described before, the degree of overestimation again is lower in the AHD procedure.

\section{Cell errors}

\section{Ghost error}

An overestimation of $\mathrm{Hb}$ concentration is also caused by the fact that erythrocyte membranes are not dissolved completely by the $\mathrm{Hb}$ reagents used. This error was estimated as follows: Samples of $20 \mu \mathrm{l}$ blood $+5 \mathrm{ml} \mathrm{HiCN}$ reagent or $20 \mu \mathrm{l}$ blood $+3 \mathrm{ml} \mathrm{AHD}$ reagent were centrifuged for $60 \mathrm{~min}$ at $20000 \mathrm{~g}$. The sedimented membranes (possibly containing nuclei of leukocytes) were resuspended in $1 / 4$ of the membranefree supernatant. The absorbance of the membranes was determined by measuring the membrane suspension versus the membrane-free supernatant. The absorbance values obtained from five determinations were 0.0015 with the $\mathrm{HiCN}$ method and 0.0010 with the AHD method. The results are given in table 2 as

Tab. 2. Error of $\mathrm{Hb}$ determination caused by erythrocytes and leukocytes

\begin{tabular}{|c|c|c|c|}
\hline Cells & Method & $\begin{array}{l}\text { Apparent } \\
\text { Hb con- } \\
\text { centration } \\
\text { [g/dl] }\end{array}$ & $\begin{array}{l}\text { Relative } \\
\text { error at } \mathrm{Hb} \\
\text { concentration } \\
\text { of } 15 \mathrm{~g} / \mathrm{dl} \\
{[\%]}\end{array}$ \\
\hline $\begin{array}{l}\text { Erythrocyte } \\
\text { ghosts }\end{array}$ & $\begin{array}{l}\text { HiCN } \\
\text { AHD }\end{array}$ & $\begin{array}{l}0.055 \\
0.035\end{array}$ & $\begin{array}{l}+0.36 \\
+0.26\end{array}$ \\
\hline \multicolumn{4}{|l|}{ Leukocytes: } \\
\hline $\begin{array}{c}\text { Normocytosis } \\
\left(5 \cdot 10^{9} / 1\right)\end{array}$ & $\begin{array}{l}\text { HiCN } \\
\text { AHD }\end{array}$ & $\begin{array}{l}0.024 \\
0.015\end{array}$ & $\begin{array}{l}+0.16 \\
+0.10\end{array}$ \\
\hline $\begin{array}{c}\text { Leukocytosis } \\
\left(50 \cdot 10^{9} / 1\right)\end{array}$ & $\begin{array}{l}\mathrm{HiCN} \\
\mathrm{AHD}\end{array}$ & $\begin{array}{l}0.24 \\
0.15\end{array}$ & $\begin{array}{l}+1.6 \\
+1.0\end{array}$ \\
\hline
\end{tabular}

the apparent $\mathrm{Hb}$ concentration, and as the relative error at $15 \mathrm{~g} / \mathrm{dl}$. In both methods the relative error due to ghosts is negligible and of no clinical importance. However, it is decreased by about a half in the new method.

\section{Leukocyte error}

Another overestimation of the $\mathrm{Hb}$ concentration is caused by the presence of leukocytes, which may not be completely dissolved in the reaction media of both $\mathrm{Hb}$ determination procedures. Leukocytes prepared from fresh blood were suspended in $\mathrm{NaCl}$ solution. The absorbance of 2 different dilutions (leukocyte count 31.6 and $\left.116 \times 10^{9} / 1\right)$ were used to calculate the results given in table 2 on the basis of equations (1) and (2). The calculated values of the relative overestimation of the $\mathrm{Hb}$ concentration under physiological conditions (leukocyte count $5 \cdot 10^{9} / 1$ ) and in leukocytosis (leukocyte count $50 \cdot 10^{9} / 1$ ) indicate that the leukocyte error is considerably lower with the AHD method than with the HiCN method, and that, however, this error is markedly increased in the case of leukocytosis with both methods.

\section{Hb errors}

These errors arise because some $\mathrm{Hb}$ species or derivatives are converted into the reaction products considerably more slowly than normal $\mathrm{Hb}$. Thus, measuring the absorbance of the sample prior to complete conversion may lead to wrong results, i.e., to an overestimation of the $\mathrm{Hb}$ concentration.

\section{Fetal $\mathrm{Hb}$}

As compared to normal $\mathrm{Hb}$, the time needed for conversion into $\mathrm{HiCN}$ is slightly increased in the case of fetal $\mathrm{Hb}$. The time course of the conversion into $\mathrm{HiCN}$, and into AHD, respectively, measured with 8 blood samples of 2 newborns, is shown in table 3, the results being expressed as the absorbance difference in percent of the value obtained after $60 \mathrm{~min}$, this value being considered as the final absorbance value.

Tab. 3. Effect of conversion rate of fetal or carboxy $\mathrm{Hb}$ on $\mathrm{Hb}$ determination expressed as relative error in percent of the absorbance value at $60 \mathrm{~min}$ (fetal $\mathrm{Hb}$ ) and at $120 \mathrm{~min}$ (carboxy $\mathrm{Hb}$ )

\begin{tabular}{|c|c|c|c|c|c|c|c|c|c|c|}
\hline \multirow[t]{2}{*}{ Hb species } & \multirow[t]{2}{*}{ Method } & \multicolumn{9}{|c|}{ Time [min] } \\
\hline & & 1 & 2 & 3 & 5 & 10 & 20 & 40 & 60 & 120 \\
\hline Fetal Hb & $\begin{array}{l}\mathrm{HiCN} \\
\mathrm{AHD}\end{array}$ & $\begin{array}{l}+4.0 \\
+1.0\end{array}$ & $\begin{array}{l}+1.6 \\
+0.0\end{array}$ & $\begin{array}{l}+0.7 \\
+0.1\end{array}$ & $\begin{array}{l}+0.4 \\
+0.1\end{array}$ & $\begin{array}{l}+0.0 \\
+0.0\end{array}$ & $\begin{array}{l}+0.0 \\
+0.0\end{array}$ & $\begin{array}{l}+0.0 \\
+0.0\end{array}$ & $\begin{array}{l}+0.0 \\
+0.0\end{array}$ & $\begin{array}{l}+0.0 \\
+0.0\end{array}$ \\
\hline Carboxy Hb & $\begin{array}{l}\text { HiCN } \\
\text { AHD }\end{array}$ & $\begin{array}{l}+16.7 \\
+\quad 1.3\end{array}$ & $\begin{array}{r}+14.5 \\
+\quad 0.1\end{array}$ & $\begin{array}{r}+13.2 \\
+\quad 0.1\end{array}$ & $\begin{array}{l}+11.1 \\
+0.1\end{array}$ & $\begin{array}{r}+8.4 \\
+0.1\end{array}$ & $\begin{array}{l}+4.6 \\
+0.1\end{array}$ & $\begin{array}{l}+3.4 \\
+0.0\end{array}$ & $\begin{array}{l}+1.6 \\
+0.0\end{array}$ & $\begin{array}{l}+0.0 \\
+0.0\end{array}$ \\
\hline
\end{tabular}


From these results it is evident that the $\mathrm{Hb}$ concentration is overestimated by $0.7 \%$ when measured after $3 \mathrm{~min}$. In contrast to these results there is practically no overestimation in the case of the AHD method, when measured after $2 \mathrm{~min}$.

\section{Carboxy $\mathrm{Hb}$}

It has been demonstrated by several authors $(5-8)$ that the conversion of carboxy $\mathrm{Hb}$ into $\mathrm{HiCN}$ is significantly slower than that of carbonmonoxide-free $\mathrm{Hb}$. The time-course of the conversion into the endproducts is given for both methods in table 3 . The results ( $n=3$ for each method) are expressed as the absorbance difference in percent of the value obtained after $120 \mathrm{~min}$, this value being considered as the final absorbance value. There is a marked positive error of absorbance values in the case of the $\mathrm{HiCN}$ method during the first $20 \mathrm{~min}$, in contrast to the values of the AHD method, in which the final absorbance value is obtained after $2 \mathrm{~min}$. Obviously, this delayed conversion of carboxy $\mathrm{Hb}$ leads to an overestimation of the $\mathrm{Hb}$ concentration, whenever carboxy $\mathrm{Hb}$ is present in the blood. Assuming a carboxy Hb concentration of $10 \%$ of the total $\mathrm{Hb}$ concentration - a realistic value in blood of smokers (maximally 12$22 \% \mathrm{COHb}$, compare table 28 in 1.c. (13)) -, a significant overestimation is obtained during the first 10 min with the HiCN method (tab. 4). The degree of overestimation is expressed as \% of the total $\mathrm{Hb}$ concentration. In contrast to the conventional method, the method presented here does not result in an overestimation in normal blood $(15 \mathrm{~g} / \mathrm{dl})$ after $2 \mathrm{~min}$.

Tab. 4. Time dependence of the relative error on $\mathrm{Hb}$ determination in the presence of carboxy $\mathrm{Hb}$. The values were calculated assuming a relative concentration of $10 \%$ carboxy $\mathrm{Hb}$

\begin{tabular}{lll}
\hline $\begin{array}{l}\text { Time difference between } \\
\text { mixing of blood with } \\
\text { corresponding Hb reagent } \\
\text { and measurement }\end{array}$ & \multicolumn{2}{l}{$\begin{array}{l}\text { Relative error in Hb concen- } \\
\text { tration at } 15 \mathrm{~g} / \mathrm{dl}\end{array}$} \\
\cline { 2 - 3 } [min] & $\begin{array}{l}\text { HiCN } \\
\text { method }\end{array}$ & $\begin{array}{l}\text { AHD } \\
\text { method } \\
{[\%]}\end{array}$ \\
\hline 1 & {$[\%]$} & {$[\%]$} \\
2 & +1.7 & +0.1 \\
3 & +1.5 & +0.0 \\
5 & +1.3 & +0.0 \\
10 & +1.1 & +0.0 \\
\hline
\end{tabular}

\section{Discussion}

The HiCN method overestimates the haemoglobin concentration as a result of errors caused by cells (4, $10)$, by normal or pathological plasma $(4,10-12)$, and by certain haemoglobin species $(5-8)$. Our own studies confirmed the literature reports of these errors. As an example, van Kampen et al. (4) found a plasma error of $+0.4 \%$ (up to $3 \%$ in some cases of low $\mathrm{Hb}$ concentration and of highly coloured plasma) and an erythrocyte error of $0.2 \%$ (varying between 0 and $0.7 \%$ ). These values are in good agreement with those found here: a plasma error in the range from $0.77 \%$ to $3.57 \%$ (tab. 1), and a ghost error of $+0.36 \%$ (tab. 2).

The corresponding values of the relative errors in the AHD method are significantly lower: normal plasma $+0.35 \%$, lipaemic plasma $+0.95 \%$, and ghosts $+0.26 \%$. The error due to delayed conversion into the end product is zero, because conversion of all haemoglobin species including fetal and carboxy-Hb is complete even after 2 minutes.

Unfortunately, all errors described here are positive errors for both methods. Therefore, a considerable overestimation of the $\mathrm{Hb}$ concentration may arise, if several small positive errors occur at the same time. Two examples may be given to demonstrate the possible effects:

1. Hb determination for a smoker, measurement 3 min after the addition of the reaction solution, haematocrit 0.45 , lipaemic plasma, normal red blood cells: The positive error (caused by plasma, lipaemia, ghosts, leukocytes, and $10 \%$ carboxy $\mathrm{Hb}$ ) amounts to $4 \%$ for the $\mathrm{HiCN}$ and to only $1.6 \%$ for the AHD method.

2. Hb determination for a newborn, measurement $3 \mathrm{~min}$ after addition of the reaction solution, haematocrit 0.30 , normal blood cells, [bilirubin] $=50$ $\mathrm{mg} / \mathrm{dl}$ : The positive error (caused by plasma, ghosts, leukocytes, bilirubin, and fetal $\mathrm{Hb}$ ) amounts to $4.9 \%$ for the $\mathrm{HiCN}$ and to only $1.8 \%$ for the AHD method.

Turbidities caused by plasma proteins and by fragments of cells are a general problem and occur whenever haemoglobin is photometrically determined in blood, irrespective of which method may be used. The composition of the HiCN reagent is a compromise with respect to the $\mathrm{pH}$ value which is slightly above neutrality $(\mathrm{pH}=7.2)$, accelerating the reaction on one side, but also favoring turbidities on the other (15). Normally, these difficulties can be minimized by the presence of a suitable detergent at a low concentration, e. g. $0.05 \mathrm{~g} / \mathrm{dl}$, which does not affect the $\mathrm{HiCN}$ spectrum. On the other hand, the AHD reagent, which is an aqueous alkaline $(\mathrm{pH}=13)$ solution of a nonionic detergent at a high concentration, e. g. $2.5 \mathrm{~g} / \mathrm{dl}$ Triton X-100, causes rapid haemolysis of the blood with subsequent denaturation and oxidation of haemoglobin by aerobic oxygen dissolved in the reagent, 


\section{Wilhelm Friedrich}

\section{Vitaming}

1988. $17 \mathrm{~cm} \mathrm{x} 24 \mathrm{~cm}$. XII, 1062 pages. Hardcover. DM 380,-; approx. US, $\$ 225.00$ ISBN 3110101447

A comprehensive, authoritative Handbook and reference source of all aspects of vitamins.

The book at a glance

O Complete and systematic overview of all water- and fat-soluble vitamins

O Introductory chapter presenting basic general information on the vitamins

O Numerous illustrations, formulas, tables, etc.

O Comprehensive and up-to-date bibliographic references at the end of each chapter

O Supplementary bibliography of publications that appeared subsequent to completion of the editorial work on the book

\section{From the Contents}

Introduction - Vitamin A and its Provitamins - Vitamin D - Vitamin E - Vitamin K . Thiamin (Vitamin $\mathrm{B}_{1}$, Aneurin) - Vitamin $\mathrm{B}_{2}$ : Riboflavin and its Bioactive Variants . Niacin: Nicotinic Acid, Nicotinamide, NAD (P) - Vitamin $B_{6} \cdot$ Folic Acid and Unconjugated Pteridines - Biotin - Pantothenic Acid - Vitamin $\mathrm{B}_{12} \cdot$ Vitamin C . Literature Supplement $\cdot$ Subject Index

\section{Potential audience}

Biochemists, Biologists, Clinicians, Pharmacologists, Toxicologists, Physiologists, Pharmacists, Nutritionists, Organic and Analytical Chemists. Institutes, Libraries 
and almost complete solubilization of the constituents of blood by micellization. This may explain the relatively low methodological crrors in the AHD procedure in comparison with the HiCN-method.

Although the errors of the HiCN method are generally not meaningful in practice, the results of the comparison of crrors is another criterion by which the newly developed AHD method is superior to the reference method. Other advantages have been discussed in detail $(1,2)$, especially the possibility of direct standardization.

\section{References}

1. Zander, R., Lang, W. \& Wolf, H. U. (1984) Clin. Chim. Acta 136, 83-93.

2. Wolf, H. U., Jang, W. \& Zander, R. (1984) Clin. Chim. Acta 136, 95-104.

3. Rick, W. (1976) In: Hämoglobinbestimmung im Vollblut. Klinische Chemie und Mikroskopie, 4th ed., pp. 47-49, Springer Verlag Berlin, Heidelberg, New York.

4. Van Kampen, E. J. \& Zijlstra, W. G. (1961) Clin. Chim. Acta 6, 538-544.

5. Van Kampen, E. J. \& Zijlstra, W. G. (1965) Advances Clin. Chem. 8,141- 187.

6. Rodkey, F. L. (1967) Clin. Chem. 13, 2-5.

7. Taylor, J. D. \& Miller, D. D. M. (1965) Amer. J. Clin. Pathol. 43, 265-271.

8. Rice, R. W. (1967) Clin. Chim. Acta 18, 89-91.

9. Heilmeyer, L. (1933) In: Medizinische Spcktrophotometric, pp. 116-117, Gustav-Fischer-Verlag, Jena.

\section{Addendum}

One point which might become more important in the future has not yet been mentioned. It is well-known that cyanide is a detrimental hayad to the environment, e. g. to fish, on aceount of its high toxicity. This is one of the reasons why Japan has already restricted the use of cyanide. Indeed, this poison is delivered into the environment in considerable amounts especially when the HiCN method is run in automatic analysers. The hazardous effect of cyanide could be abolished by substituting the HiCN method by the AHD method. Triton $X-100$ is biologically degradable to at least $85 \%$, and $\mathrm{NaOH}$ may be neutralized to $\mathrm{NaCl}$ prior to the release to the environment. $\mathrm{NaCl}$ is certainly not hayardous in quantities produced by the AHD method.

10. Matsubara, T., Okuzono, H. \& Tamagawa, S. (1972) In: Modern Concepts in Hematology, Symposia of the International Committec for Standardization in Hematology (Izak, G. \& Lcwis, S. M., cds.) pp. 29-43, Acadcmic Press, New York, London.

11. Grecn, P. \& Tcal, C. F. J. (1959) Amer. J. Clin. Pathol. 32, 216-217.

12. Vanzetti, G. \& Franzini, C. (1972) In: Modern Concepts in Hematology, Symposia of the International Committec for Standardisation in Hematology (Izak, G. \& Lewis, S. M., eds.) pp. 44-53, Academic Press, New York, London.

13. Pankow, D. (1981) Toxikologie des Kohlenmonoxids, VEB Verlag Volk und Gesundheit, Berlin.

14. van Kampen, E. J. \& Zijlstra, W. G. (1983) Adv. Clin. Chem. 23, 199-257.

15. van Asscndelf, O. W. \& Parvin, R. M. (1982) In: Advances in Hematological Methods: The Blood Count (van Assendelft, O. W. \& England, J. M., eds.) pp. 13-28, CRC Press, Boca Raton, Florida.

Prof. Dr. H. U. Wolf

Abtcilung Pharmakologje und Toxikologic der Universität Ulm

Oberer Eselsberg N 26

D-7900 UIm/Donau 
